تأثير روشهاى مختلف خاكورزى در تناوبهاى گندم- ينبه و گندم - كنجد بر ميزان ترسيب كربن در خاك

\author{
محمد جواد روستا'، صادق افضلى نيا' و علىداد كرمى

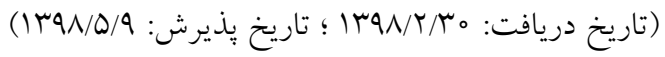

جكيده

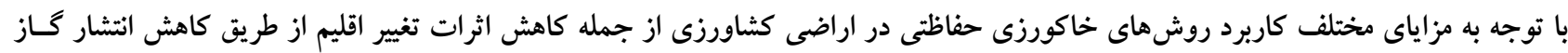

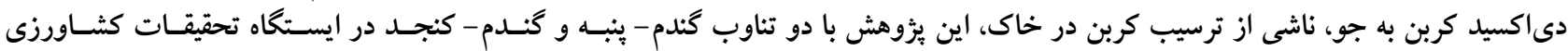

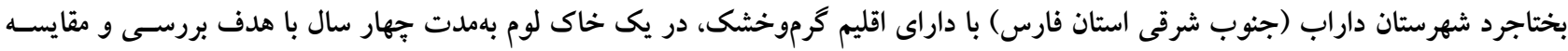

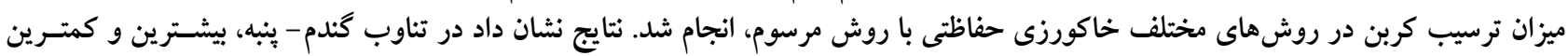

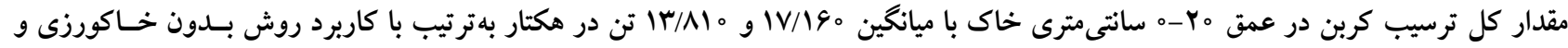

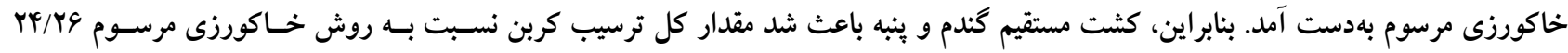

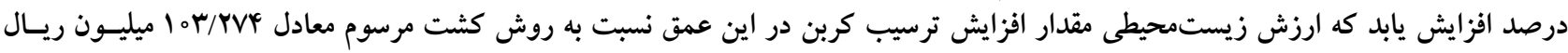

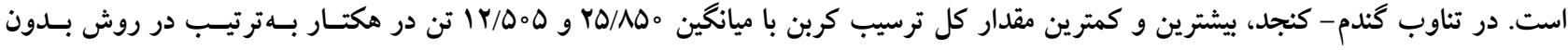

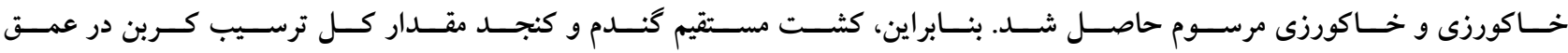

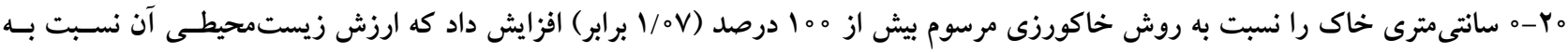

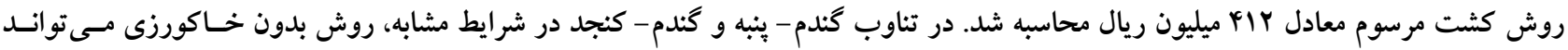
جايخزين روش خاكورزى مرسوم شود مادو

وازههاى كليدى: استان فارس، ترسيب كربن، تناوب زراعى، خاكورزى حفاظتى

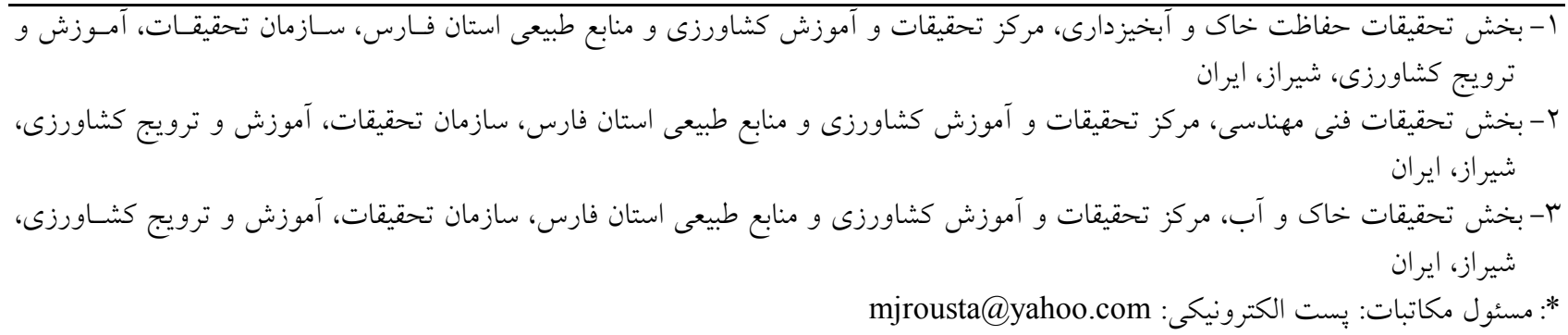


عمليات مناسب كشاورزى شامل روشهـاى كـم خـاكورزى يـا

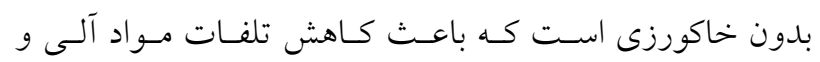

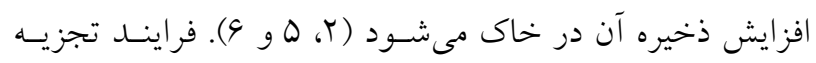

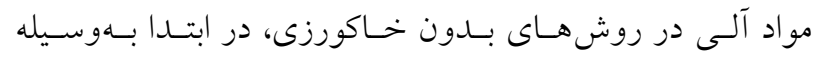

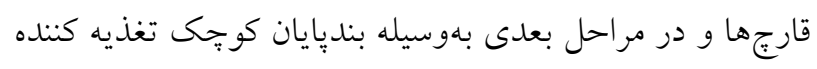

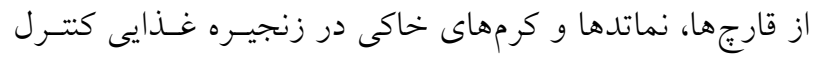

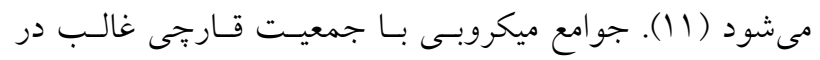

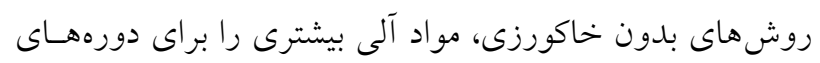

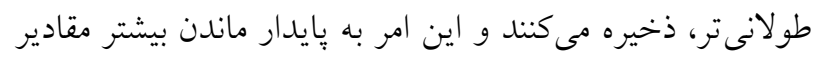

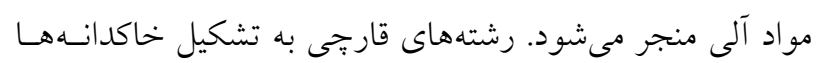

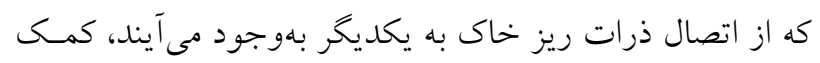

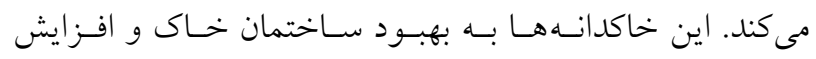

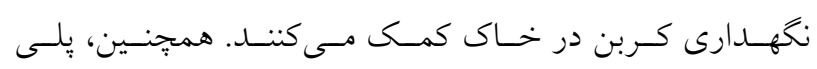

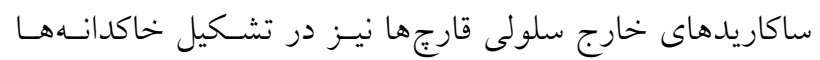

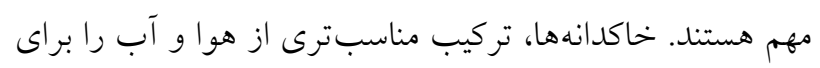
رشد كياه در خاك فراهم مى كنند.

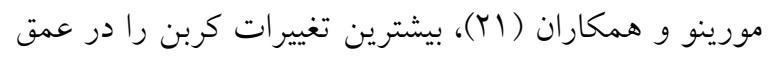

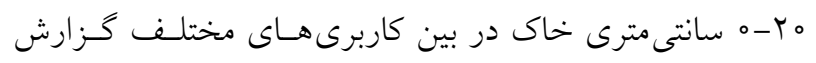

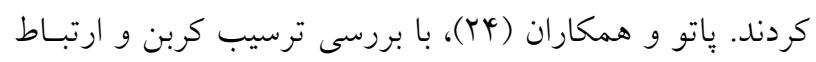

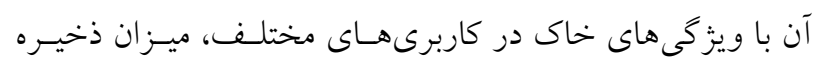

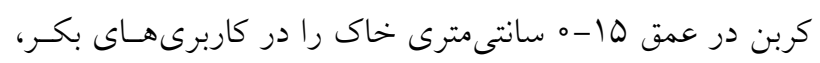

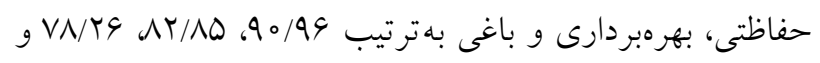

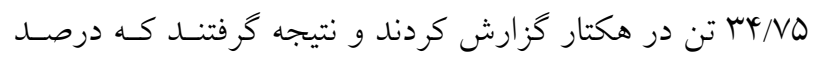

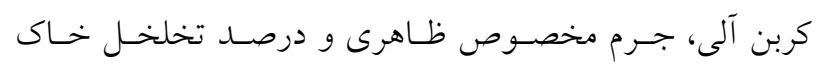

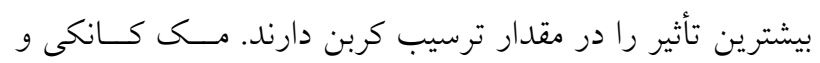

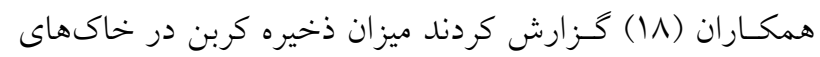
بدون شخم در مقايسه با خاكهــاى شـخم خـورده بــهـ مقـدار

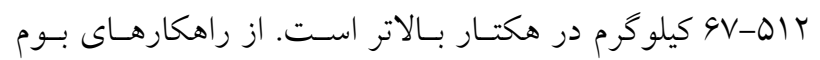
شـناختى مـؤثر در كـاهش غلظـت دى اكسـيد كـربن در جـو و و

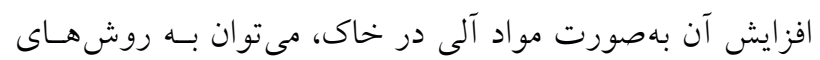

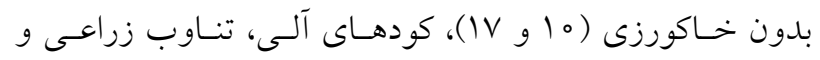

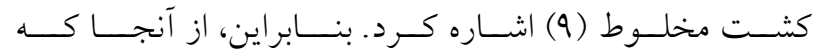

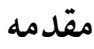

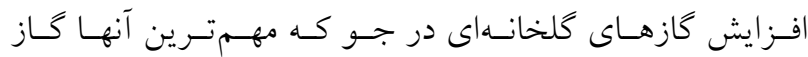

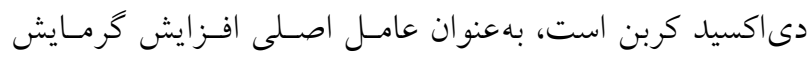

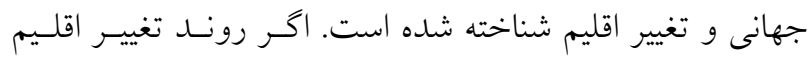

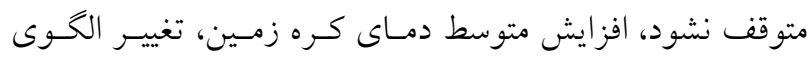

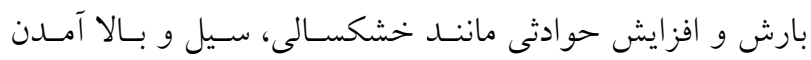

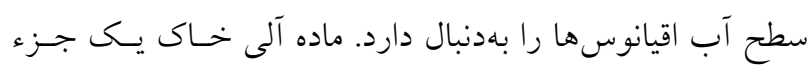

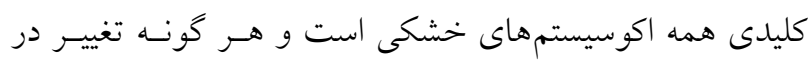

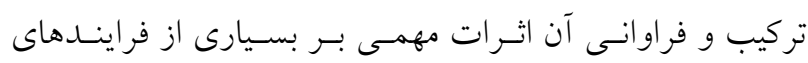

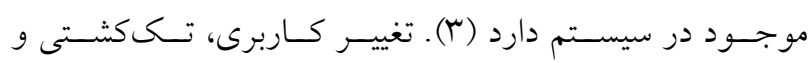

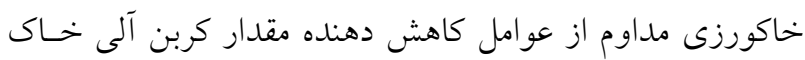

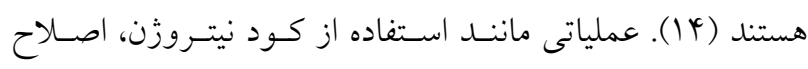

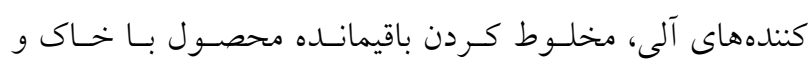

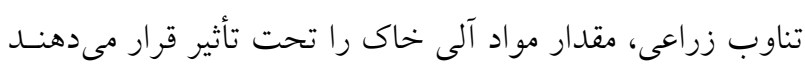

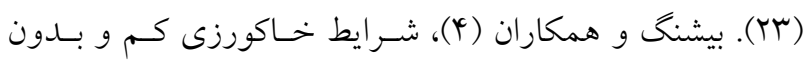

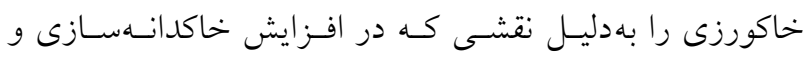

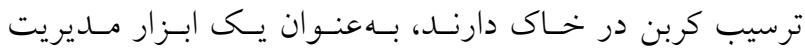
كشاورزى در خاكهاى خشك توصيه مى كنند.

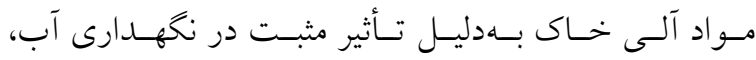

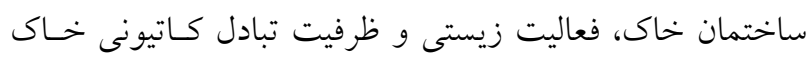

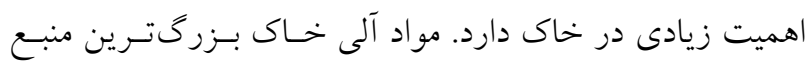

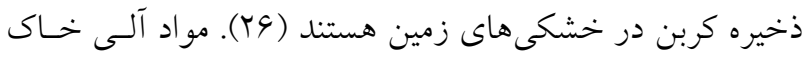

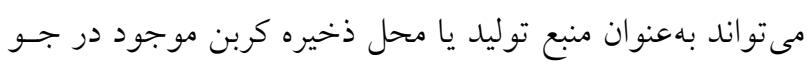

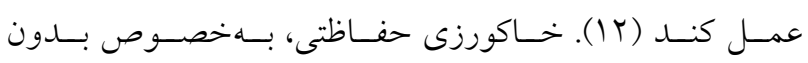

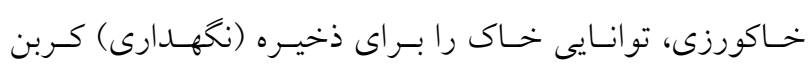

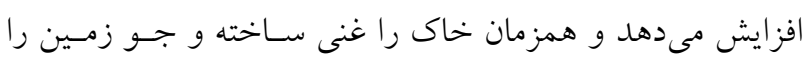

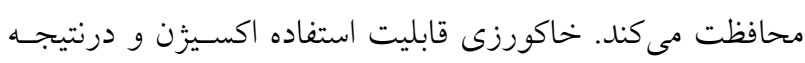

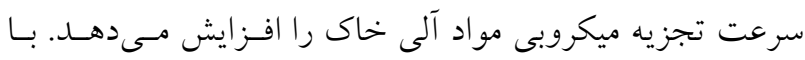

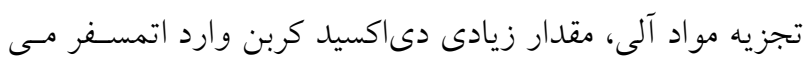

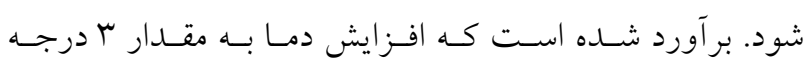

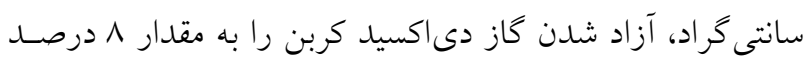

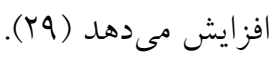


شد. بهمنظور تعيين ويزگى هاى فيزيكى و شيميايى خاك، قبل از

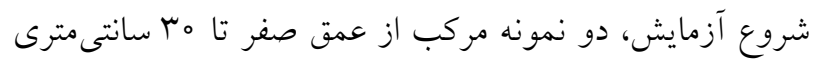

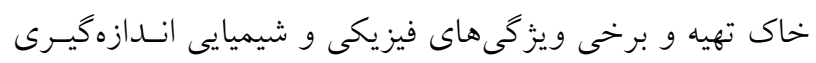
شدند (جدولهاى او ب)

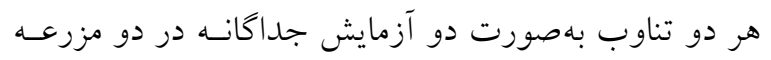

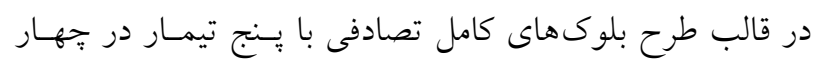

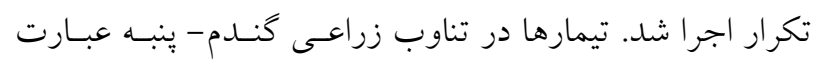

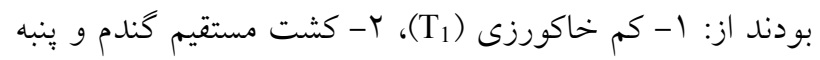

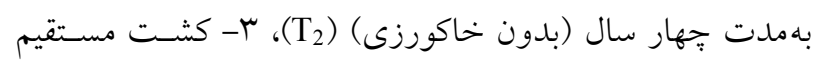

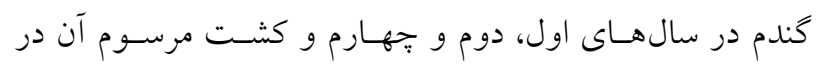

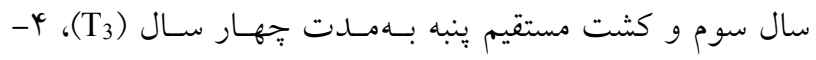

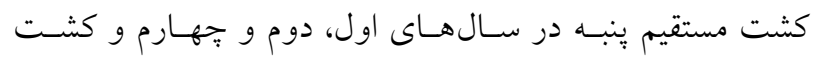

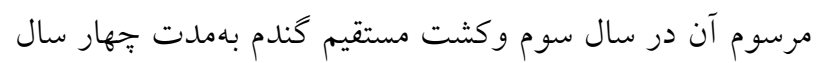
(T)

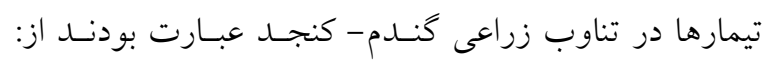
1-كم خاكورزى (C)

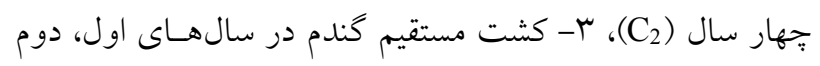

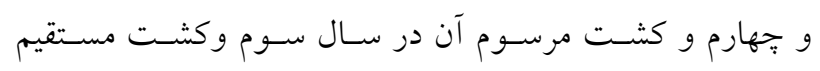

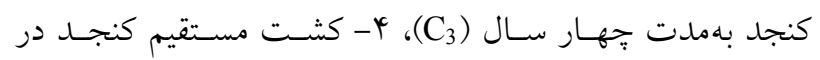

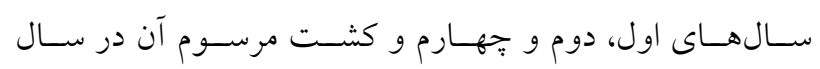

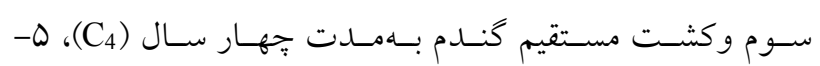

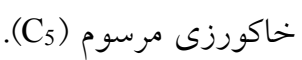

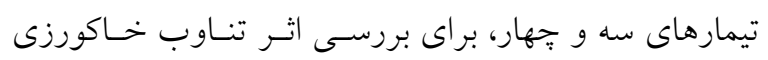

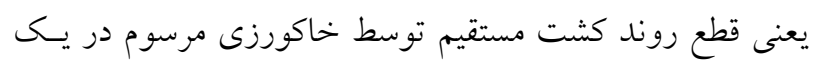

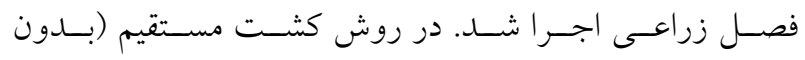

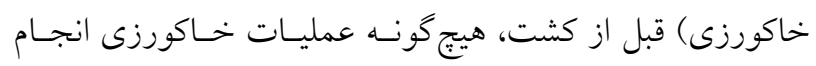

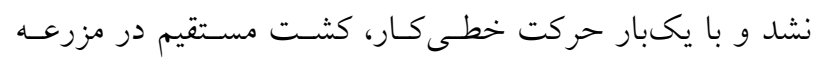
انجام كرفت. در روش كم خاكورزى، از يـك دستّاه خـاكورز مركب استفاده شد و عمليات خاكورزى در يـك مرحلـه دونه انجـام

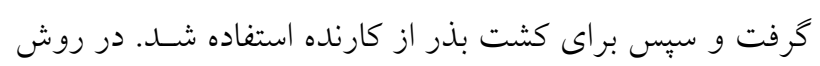

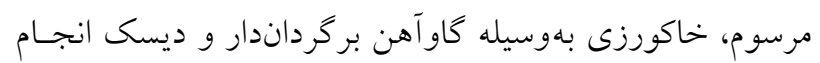

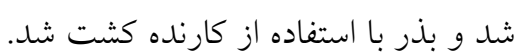

زيست توده كياهى در ترسيب كربن و كاهش غلظت ايسن كـاز

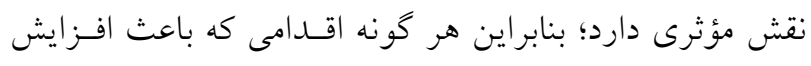
يوشش كياهى شود، بهطور غيرمستقيم در بهبود ترسيب كربن

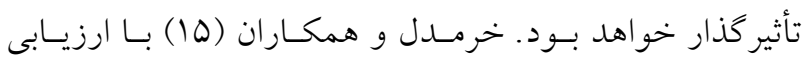
توانايى بالقوه ترسيب كـربن مـزارع كلـزا در اسـتان خراســان

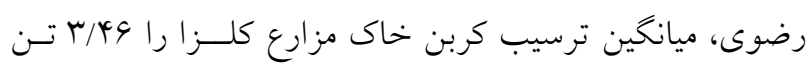

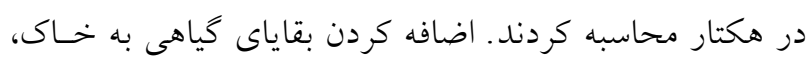

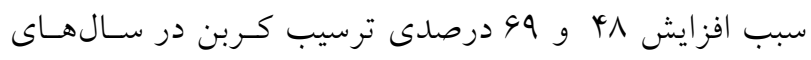

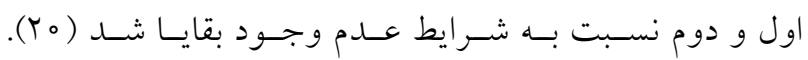

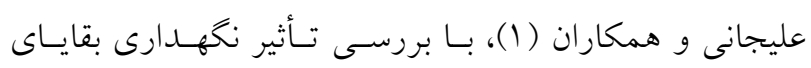

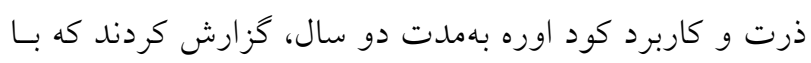

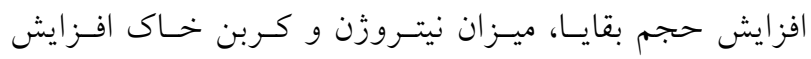

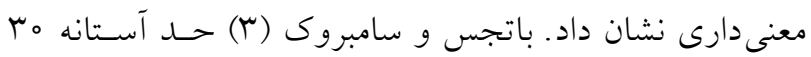
تن در هكتار را براى جداسازى خاكهاى داراى كمبود كـربن

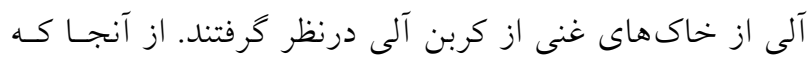

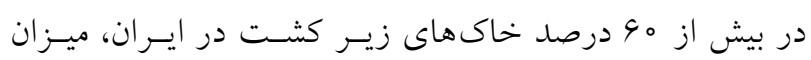

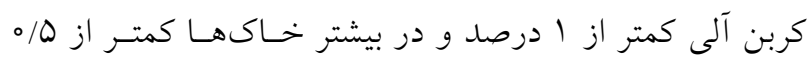

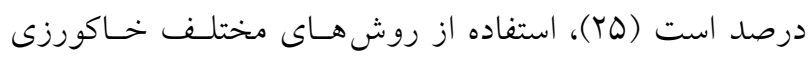

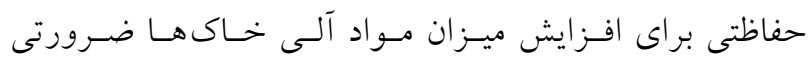

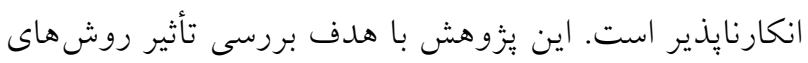

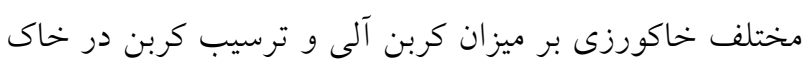

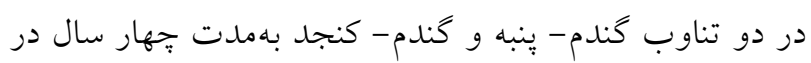

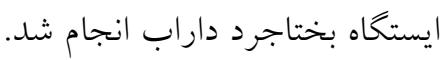

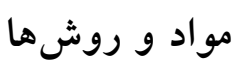

اين بررسى در ايستخاه تحقيقات كشـاورزى بختـاجرد واقـع در

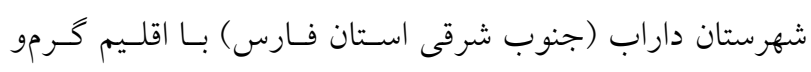

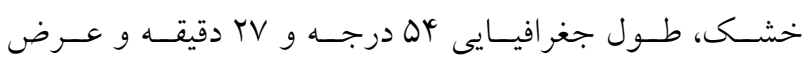

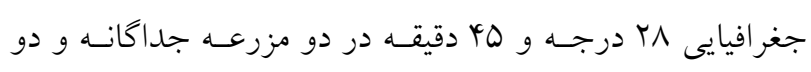

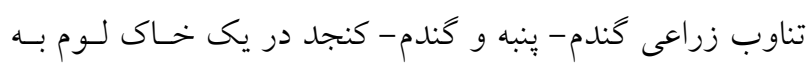

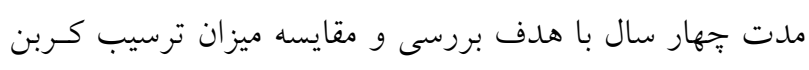
در روشهاى مختلف خاكورزى حفاظتى با روش مرسوم، انجام 
جدول ا. برخى ويزّكىهاى فيزيكى و شيميايى خاك محل اجراى آزمايش در تناوب گندم- ينبه

\begin{tabular}{|c|c|c|c|c|c|c|c|c|c|}
\hline 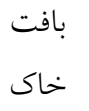 & شن & (\%) & سيلت & $\begin{array}{c}\text { يتاسيم قابل جذب } \\
\text { (mg/kg) }\end{array}$ & $\begin{array}{c}\text { فسفر قابل جذب } \\
\text { (mg/kg) }\end{array}$ & $\begin{array}{c}\text { O.C } \\
(\%)\end{array}$ & $\mathrm{pH}$ & $\begin{array}{c}\text { EC } \\
(\mathrm{dS} / \mathrm{m})\end{array}$ & $\begin{array}{l}\text { عمق } \\
\text { (cm) }\end{array}$ \\
\hline لوم & $r \Delta / \Delta$ & $|V /|$ & $\Psi \mathrm{V} / \mathrm{Q}$ & $10 \mathrm{r}$ & $0 / Q$ & $\circ / \Delta V$ & $V / 9$ & $1 / 1$ & $0-10$ \\
\hline لوم & $r \varphi / q$ & $19 / 1$ & $49 / 1$ & 90 & $Y / N$ & $\circ / \Delta r$ & $V / 9$ & o/VG & $10-r_{0}$ \\
\hline
\end{tabular}

جدول r. برخى ويزّى هاى فيزيكى و شيميايى خاك محل اجراى آزمايش در تناوب گندم- كنجد

\begin{tabular}{|c|c|c|c|c|c|c|c|c|c|}
\hline 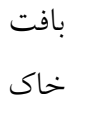 & شن & 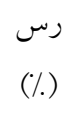 & سيلت & $\begin{array}{c}\text { يتاسيم قابل جذب } \\
\text { (mg/kg) }\end{array}$ & $\begin{array}{c}\text { فسفر قابل جذب } \\
\text { (mg/kg) }\end{array}$ & $\begin{array}{l}\text { O.C } \\
(\%)\end{array}$ & $\mathrm{pH}$ & $\begin{array}{c}\text { EC } \\
(\mathrm{dS} / \mathrm{m})\end{array}$ & $\begin{array}{l}\text { عمق } \\
(\mathrm{cm})\end{array}$ \\
\hline لوم & $\uparrow 9 / 0$ & $1 N / \circ$ & $r 9 / 0$ & TrT/4 & $r / q T$ & $0 / 9 \mathrm{~V}$ & $V / 9$ & $1 / r Y$ & $0-10$ \\
\hline لوم & $\uparrow q / 。$ & $1 N / 0$ & $\Gamma \mathrm{T} / 0$ & $199 / 9$ & $r / V \Lambda$ & o/Q & $\mathrm{V} / \mathrm{\Lambda}$ & ०/A & 10-Yo \\
\hline
\end{tabular}

براى تعيين جرم مخصوص ظاهرى خاك، قبل از شروع آزمايش

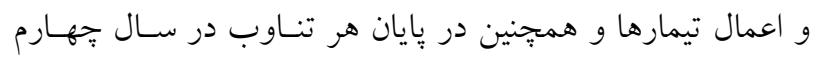

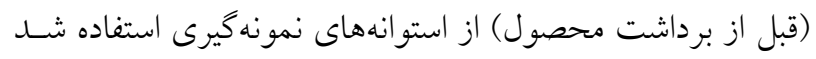

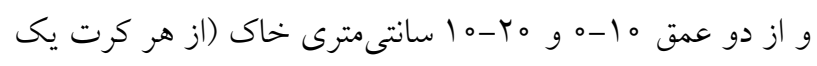

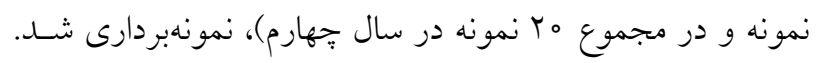

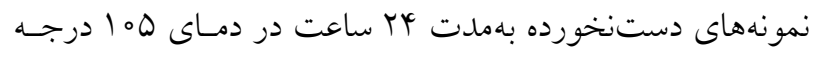

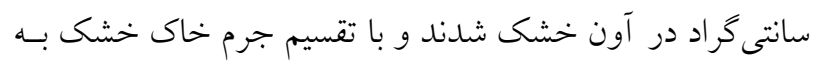

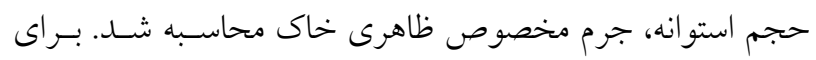

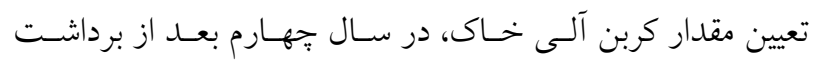

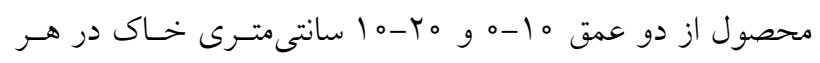

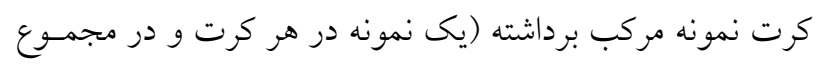

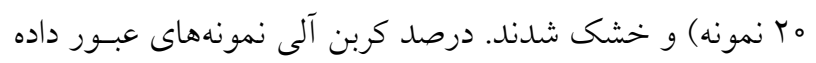
شده از الك دو ميلى مترى، اندازهيرى شد و ميزان ترسيب كـربن با استفاده از رابطه ا محاسبه شد (1):

$$
\mathrm{Cs}=\mathrm{O} . \mathrm{C} \times \mathrm{BD} \times \mathrm{D} \times \circ / 1
$$

Cs ميزان كربن ترسيب شده در خاك (مكاكرم در هكتار) ميزان كربن آلى خاى (كرم دركيلو گرم خاك) :O.C

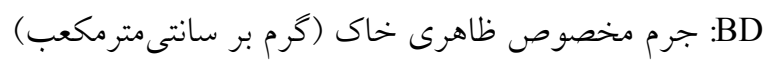
D ضخامت لايه خاى (سانتى متر) D

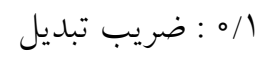

مزرعه آزمايش در شروع يزوهش در حالت آيش بود؛ بنابراين در

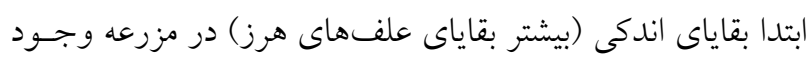

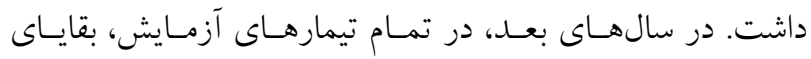

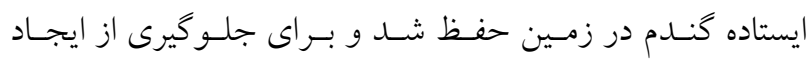

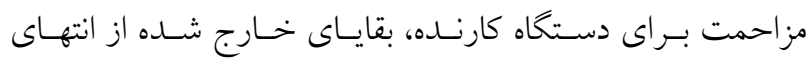

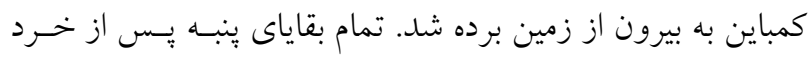

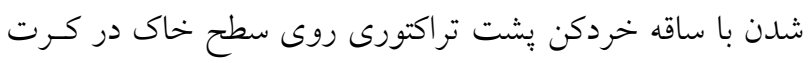

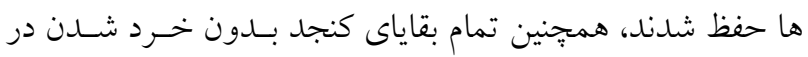

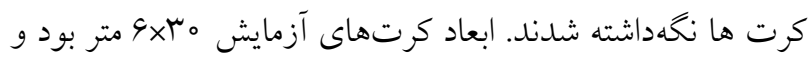

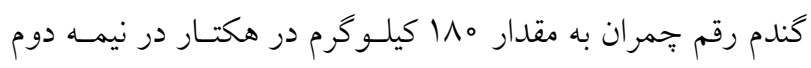

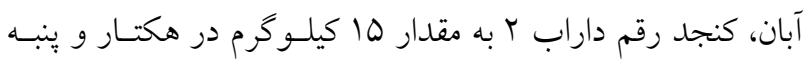

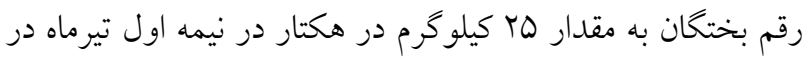

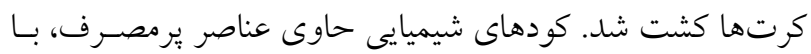

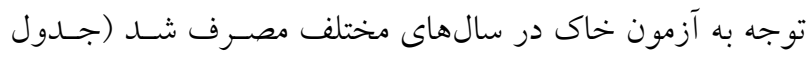
r). كودهاى سويرفسفات ترييل و سولفات بتاسيم و يكسوم كود اوره در زمان كاشت و توسط كارنده به كرتهـا داده شــد و بقيـهـ كود اوره به نسبت مساوى در دو مرحلـه بـهصورت سـرك و بــاــا دست در مزرعه بخش شد. ساير عمليات زراعسى شـامل آبيـارى

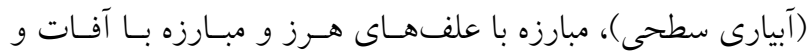

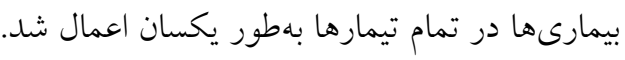


جدول r. كودهاى شيميايى مورد استفاده در تيمارها در سالهاى مختلف (كيلوگرم در هكتار)

\begin{tabular}{|c|c|c|c|}
\hline سولفات يتاسيم & سويرفسفات ترييل & اوره & سال \\
\hline 100 & 100 & Yoo & سال اول \\
\hline Q० & 100 & Yoo & سال دوم \\
\hline Q. & 100 & yoo & سال سوم \\
\hline Q. & 100 & $y \circ 0$ & سال جهارم \\
\hline
\end{tabular}

نتايج مقايسه ميانخين ميـزان مـواد آلى در عمـقهـاى ه ا-ه و

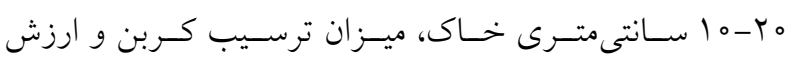

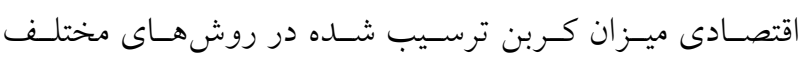

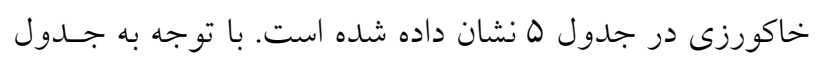
ه مشخص مىشود كه يُ از جهار سال استفاده از روش بـدون

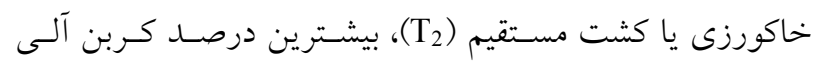
خاك با ميانخين V9/ درصد و بيشترين ميزان ترسيب كـربن بـا

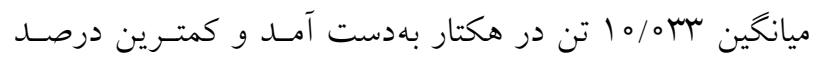
كربن آلى خاى و كمترين ميزان ترسيب كـربن در روش كشـت مئس

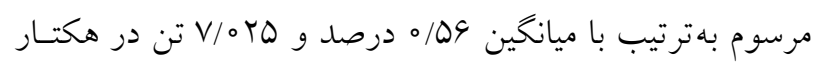

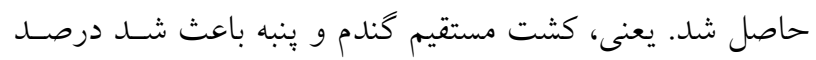

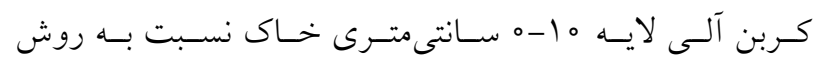

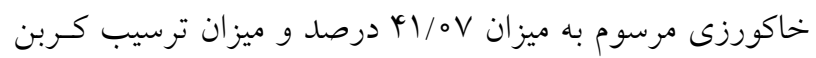
به ميزان HY/AY

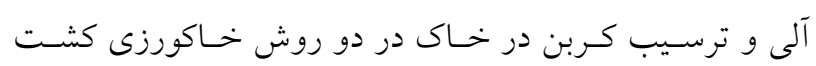
مستقيم ينبه و كشت مرسوم گندم در سال سوم و كشت مستقيم كندم (T4) و كشت مرسوم پِنبه در سال سوم (T3) كمتر از ميزان افزايش ناشى از كاربرد روش خاكورزى كشت مستقيم كنـدم و ينبه بود كه نشاندهنده تأثير منفى علدم استمرار كشت مسـتقيم و قطع آن با خاكورزى مرسوم (تناوب خاكورزى) بر درصد كربن

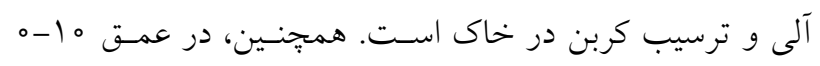

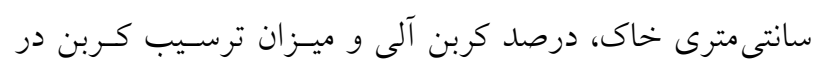
خاك ناشى از كاربرد روش كـم خـاكورزى (T) نيـز بيشـتر از درصد كربن آلى و ميزان ترسيب كربن در خاك ناشى از كاربرد

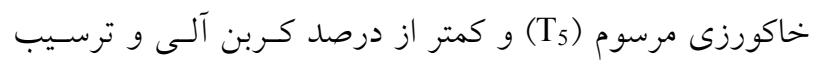
كربن در خاك در روش كشت مستقيم (T2) بود. كاهش درصــ
با درنظر گرفتن اينكه هر تن كربن معادل بـا I/ V تـن گـاز دى اكسيد كربن است، مقدار معادل گاز دىاكسيد كربن كـه از هـوا در خاى بهصورت كربن آلى ترسيب شده محاسبه شـد. سـبس، ارزش اقتصـادى - زيسـتمحيطى مقـدار كـربن ترسـيب شـده براساس بيشنهاد ريورز (YV)، كه ميزان ماليـات بـر كـربن را بـهـ

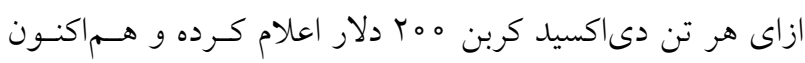

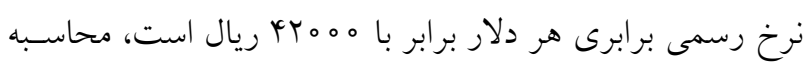

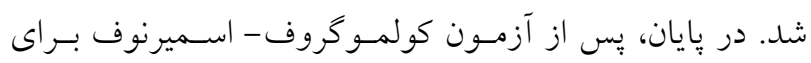
بررسى نرمال بودن، دادههاى بهدست آمده با استفاده از نرمافـزار SAS آزمون جند دامنهاى دانكن در سطح ه درصد مقايسه شدند.

\section{نتايج و بحث} تناوب كندم- ينبه نتايج تجزيه واريانس تـأثير روشهــاى مختلـف خـاكورزى بــر

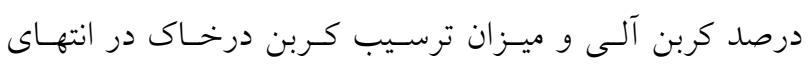
اجراى آزمايش در جدول ث آمده است. با توجه به اين جـدول،

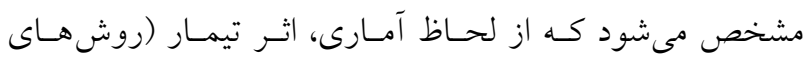
مختلف خاكورزى) بر درصد كربن آلى و ميزان ترسـيب كـربن در عمق • ا-ه سانتى مترى خـاك در سـطح ا درصـد معنسى دار

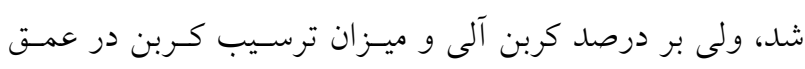

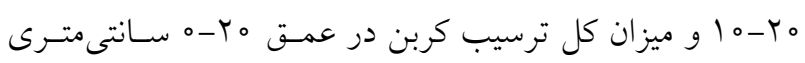
خاى تأثير معنى دارى نداشت. بنابراين، بهدليـل انجـام عمليـات زراعى و حفظ بقايا در سطح خاك، در روشهـاى خـاكورزى و بهخصوص خاكورزى حفاظتى فقط ميزان مواد آلى لايه سطحى خاك به ميزان بيشترى تحت تأثير قرار گرفته است. 


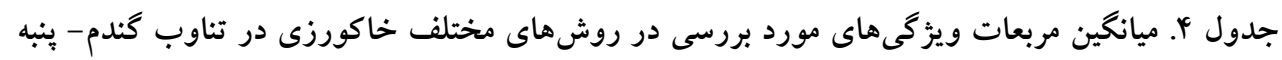

\begin{tabular}{|c|c|c|c|c|c|c|}
\hline ميزان كل ترسيب كربن & 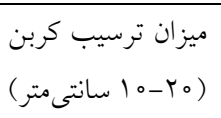 & ميزان ترسيب كربن & 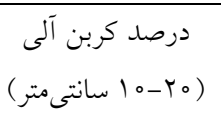 & (مرصد كربن آلى & درجه آزادى & منابع تغييرات \\
\hline N/NFIT & $1 / 4949$ & T/OTAS & \%०VV & ०/OYVA & $r$ & تكرار \\
\hline $9 / 994 \wedge^{\mathrm{ns}}$ & o/TYYQ ns & $\Delta / \Upsilon ৭ \Delta \Delta^{* *}$ &.$/ 001 \mathrm{Vns}$ & o & $r$ & تيمار \\
\hline$r / 9 \circ 19$ & $1 / 1401$ & -NANA & $\% 10090$ & $\% / 0 \triangle 9$ & Ir & خطا \\
\hline $10 / 49$ & $10 / 90$ & $10 / 94$ & $|N / r|$ & $11 / 0 \mathrm{~V}$ & & ضريب تغييرات \\
\hline
\end{tabular}

جدول ه. مقايسه ميانگين ويزگ هاى اندازهيرى شده در روشهاى مختلف خاكورزى در تناوب كندم- ينبه"

\begin{tabular}{|c|c|c|c|c|c|c|}
\hline \multirow{2}{*}{ ارزش اقتصادى- زيستمحيط } & \multirow{2}{*}{ ميزان كل ترسيب كربن } & \multicolumn{2}{|c|}{ عمق هץ-ه ا سانتىمتر } & \multicolumn{2}{|c|}{ عمق • ا-ه سانتىمتر } & \multirow{2}{*}{ خاكورزى روش } \\
\hline & & ميزان ترسيب كربن & 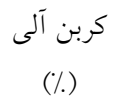 & ميزان ترسيب كربن & $\begin{array}{c}\text { كربن آلى } \\
\text { (\%) }\end{array}$ & \\
\hline KY/YMY & $10 / 1 \wedge \circ a b$ & $9 / 44 \Lambda^{a}$ & $\circ / 00^{a}$ & $N / N \mid r^{a b}$ & $\circ / 9 \wedge a b$ & $\mathrm{~T}_{1}$ \\
\hline $10 \% / T V E$ & $1 V / 190 \mathrm{a}$ & $V / Y_{\Lambda}{ }^{a}$ & $\circ / \Delta \Delta^{a}$ & 10/0rra & $\circ / v q^{a}$ & $\mathrm{~T}_{2}$ \\
\hline TV/YYI & $14 / 99 r^{a b}$ & $9 / 09 \Lambda^{a}$ & $\circ / 00^{a}$ & $N / T Y D^{b c}$ & $0 / 9$ cbc & $\mathrm{T}_{3}$ \\
\hline VI/YIT & $19 / 1 r_{0} \mathrm{ab}$ & $9 / 100 \mathrm{a}$ & o/Qra & $9 / \pi / D_{a b}$ & $\circ N F^{b b}$ & $\mathrm{~T}_{4}$ \\
\hline - & $|r / \Lambda| \circ b$ & $9 / N \wedge D^{a}$ & $\circ / \Delta r^{a}$ & $V / \circ T Q^{c}$ & $\circ / \Delta G^{c}$ & $\mathrm{~T}_{5}$ \\
\hline
\end{tabular}

* در هر ستون، ميانكينهاى داراى حروف مشترى، از نظر آمارى با آزمون دانكن در سطح احتمال ه درصد اختلاف معنى دارى ندارند.

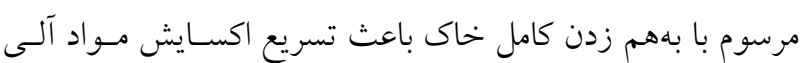

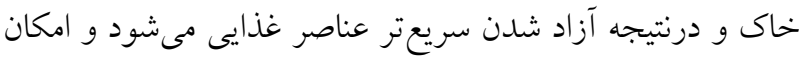

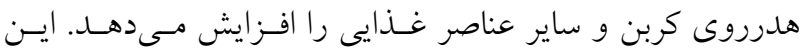

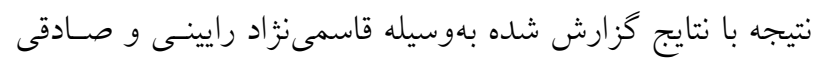

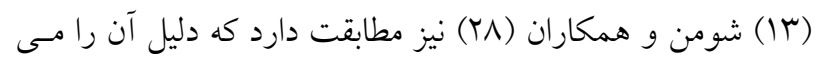
توان روند تدريجى تجزيه لاشبرى و تبــيل بـهـ هومسوس كـهـ از لايههاى سطحى خاك آغاز مى شـود دانسـت. سـومر و همكــاران

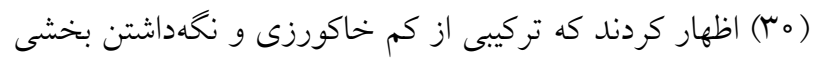

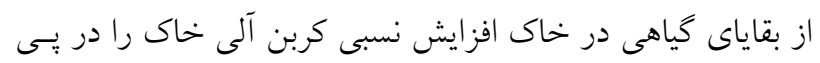

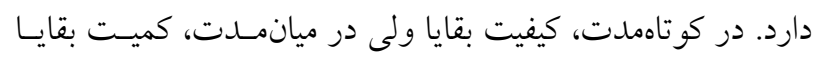

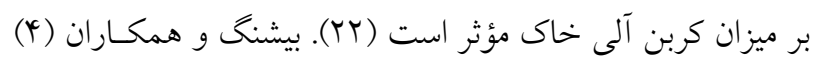

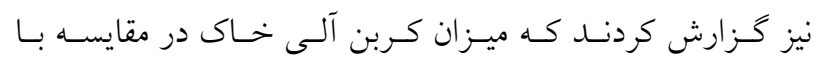

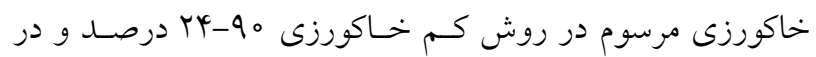

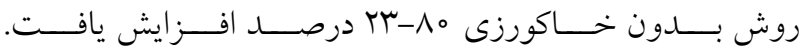

كربن آلى و ميزان ترسيب كـربن در خـاك در روش خـاكورزى

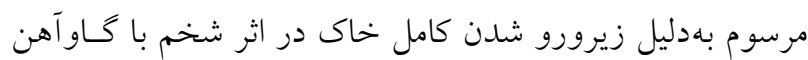
بركرداندار است. زيرا بههم خوردن خاك باعـث تهويسه بيشـتر

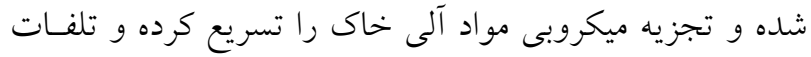
آن را افزايش مىدهد. مقايسه ميانخين درصد كربن آلى و مقدار

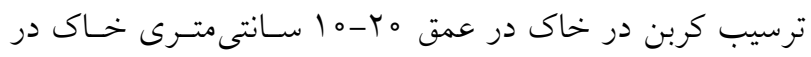

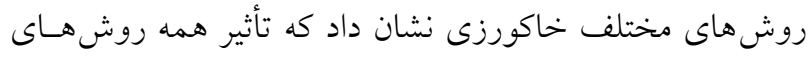

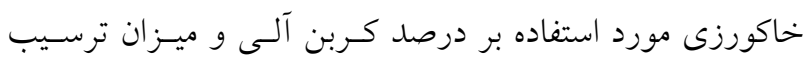

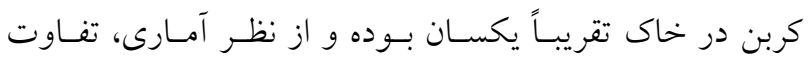

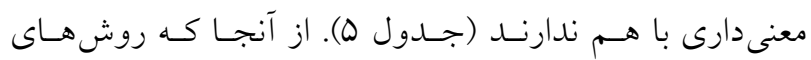

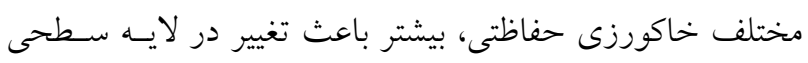

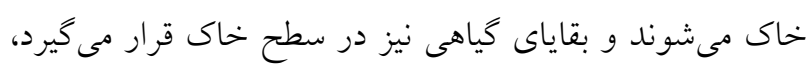

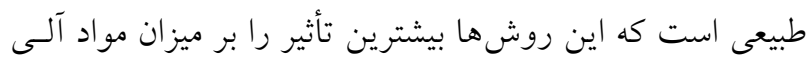

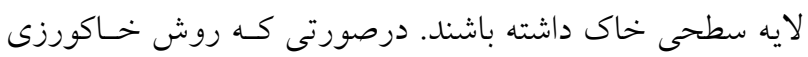


جدول 9. ميانخين مربعات ويزّكىهاى مورد بررسى در روشهاى مختلف خاكورزى در تناوب گندم - كنجد

\begin{tabular}{|c|c|c|c|c|c|c|}
\hline 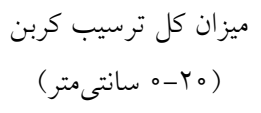 & 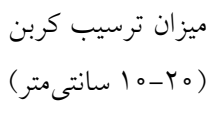 & 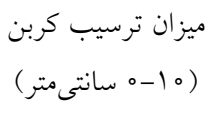 & 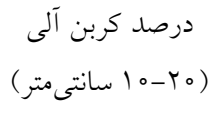 & 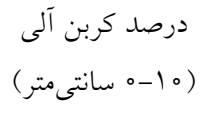 & درجه آزادى & منابع تغييرات \\
\hline $11 / 0 Y q Y$ & $|Y /| \mid Y \circ$ & -/NQYY & $0 / 9 V \times q$ & $\circ / r V \Psi \Lambda$ & r & تكرار \\
\hline $91 /$ Tq4i** & 11/०ᄉrY* & $Y \Psi / Y \circ V G * *$ & OIGYTO* & $0 /$ Y991** & $\varphi$ & تيمار \\
\hline$r / \circ \Delta \Delta Q$ & T/QVVT & 1/KGTM & .10100 & $\wedge r / 1 r q 9$ & Ir & خطا \\
\hline $9 / 0 T$ & $1 V / 90$ & $11 / 1 \mathrm{~V}$ & $|1 / 1|$ & $r Q / \circ G$ & & ضريب تغييرات \\
\hline
\end{tabular}

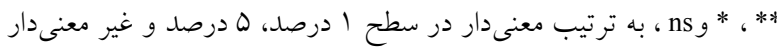

سطح ا درصد معنى دار شد. با توجه بـه اينكسه در روشهـاى خاكورزى حفاظتى، خاك به ميزان كمترى بههــم خـورده مسى شود و بيش از •ه درصد از بقاياى گياهى در سطح خاى نخه داشته مىشود، بنابراين، معنى دار بودن اثر خاكورزى بـر كـربن آلى و ميزان ترسـيب كـربن در خـاك در ايسن يـزَوهش قابـل توجيه است.

نتايج مقايسه ميانخين ميـزان كـربن آلسى و ميـزان ترسـيب

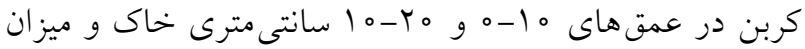

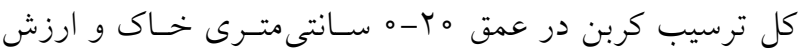
اقتصـادى - زيسـت محيطـى ميـزان كـــبن ترسـيب شـــه در روش هاى مختلـف خـاكورزى در جــدول V نشـان داده شـده است. با توجه به جدول V مشخص مى شود كه يسس از جهـار سال استفاده از روش بدون خاكورزى يا كشت مسـتقيم (C2)،

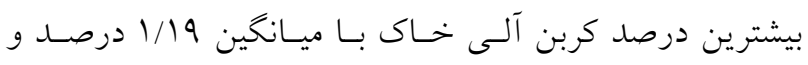
بيشترين ميزان ترسيب كربن با ميانخين ه9ه/ه ا تن در هكتـار در عمق • ا-ه سانتى مترى خاك، بهدست آمد. كمترين درصد كربن آلى خاى و كمترين ميزان ترسيب كربن در روش كشت مرسوم (C5) به ترتيب با ميانخين •D/ه درصد و هاب/ هكتار حاصل شد. يعنى جهار سال كشت مرسوم گندم و كنجد باعث شد ميزان كربن آلى خاك در عمق • ا-ه سانتىمتـرى، از

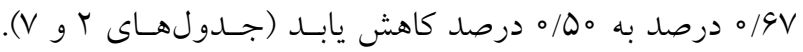
شارما و همكاران (Y9) نيز گزارش كردند † أ سال كشت مداوم، بدون اضافه كردن هيج گونه بقاياى گياهى، مقدار مواد آلى خاى

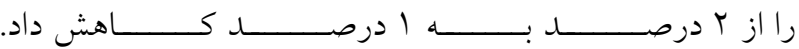

يس از جهار سال كاربرد روش بدون خـاكورزى يـا كشـت مستقيم (T2)، بيشـترين ميـزان كـل ترسـيب كـربن بــا ميـانخين IV/190

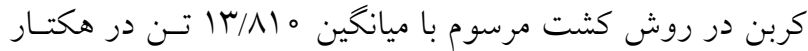
حاصل شد. يعنى، كشت مستقيم گثندم و يُنبه باعـث شـــ ميـزان كل ترسيب كربن در عمق •Y-ه سانتى متـرى خـاك نسـبت بـه

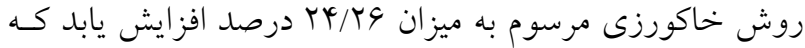
ارزش زيستمحيطى ميـزان كـل ترسـيب كـربن در ايـن عمـق

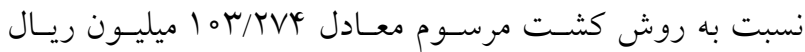
است. نتيجه يزوهش بِالم و همكاران (Yr) نشان داد كه تركيبى از تناوب زراعى و بدون خاكورزى در مقايسـه بـا سيسـتم تـك كشتى باعث افزايش بيشتر ميزان كربن ترسـيب شـده در خـاى

تناوب كندم- كنجد نتايج تجزيه واريانس تأثير روشهاى مختلـف خـاكورزى بـر درصد كربن آلى و ميزان ترسـيب كـربن در خـاك در انتهـاى اجراى آزمايش در جدول 9 آمده است. نتايج تجزيه واريـانس تأثير روشهاى مختلف خاكورزى بر درصد كربن آلى و ميزان ترسيب كربن در خاك در انتهاى سال جهارم نشـان داد كـه از نظر آمارى، اين تأثير در عمق ه ا-ه سانتى متر خاى در سـطح ا درصد و در عمق هץ-ه سانتى متر خاك درسـطح ه درصــ معنى دار است (جدول 9). همحِنين، تأثير روش هاى خاكورزى بر ميزان كل ترسيب كربن در عمق •r-هـ سانتى مترى خاك در 
جدول V. مقايسه ميانخين ويزّگىهاى مورد بررسى در روشهاى مختلف خاكورزى در تناوب گندم - كنجد"

\begin{tabular}{|c|c|c|c|c|c|c|}
\hline \multirow{3}{*}{$\begin{array}{c}\text { ارزش اقتصادى- زيستمحيطى نسبت } \\
\text { به روش مرسوم }\end{array}$} & \multirow{3}{*}{$\begin{array}{c}\text { ميزان كل ترسيب كربن } \\
\text { (t/ha) }\end{array}$} & \multicolumn{2}{|c|}{ عمق •Y-ه ا سانتى متر } & \multicolumn{2}{|c|}{ عمق • ا-ه سانتى متر } & \multirow{3}{*}{ 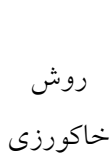 } \\
\hline & & ميزان ترسيب كربن & كربن آلى & ميز ان ترسيب كربن & كربن آلى & \\
\hline & & $(\mathrm{t} / \mathrm{ha})$ & $(\%)$ & $(\mathrm{t} / \mathrm{ha})$ & $(\%)$ & \\
\hline$Y Y Y / Y V D$ & $\Gamma \circ / \mu \mu^{b}$ & a & $\circ / V Y^{a}$ & $11 / 010^{b}$ & $\circ / \wedge V^{b}$ & $\mathrm{C}_{1}$ \\
\hline FIT/01GT & $r Q / \Lambda V \circ a$ & $1 \circ / \Delta \vee \Delta^{a}$ & $\circ / q^{a}$ & $10 / Y 90^{a}$ & $1 / 19^{a}$ & $\mathrm{C}_{2}$ \\
\hline$r M r / Q \circ Y$ & $19 / V 9 \wedge b$ & $\wedge / \wedge \bowtie \circ a$ & $0 / 9 \mathrm{Va}$ & $10 / 911 \mathrm{~b}$ & $\circ / \wedge \varphi b$ & $\mathrm{C}_{3}$ \\
\hline INH/9VT & $\mid N / 4 q \mu^{\mathrm{b}}$ & $q / V V \mu^{\text {a }}$ & $\circ / \mu^{a}$ & $1 / 99 \circ \mathrm{c}$ & $\circ / 9 \wedge^{b c}$ & $\mathrm{C}_{4}$ \\
\hline- & $1 \Gamma / \Delta \circ \Delta^{c}$ & $9 / 119 \mathrm{~b}$ & $\circ / 4 V^{b}$ & $9 / \pi 1 Q^{\mathrm{d}}$ & $\circ / \mathrm{Q} \circ \mathrm{c}$ & $\mathrm{C}_{5}$ \\
\hline
\end{tabular}

* در هر ستون، ميانخينهاى داراى حروف مشترى، از نظر آمارى با آزمون دانكن در سطح احتمال ه درصد اختلاف معنىدارى ندارند.

روش هاى مختلف خاكورزى در تناوب كندم - كنجد، نشـان داد كه تأثير همه روشهاى خاكورزى مورد استفاده بر درصد كـربن آلـى و ميـزان ترسـيب كـربن در خــاك در مقايسـه بـا روش خاكورزى مرسوم بيشتر بوده و از نظر آمارى، اين تفاوتهـا در

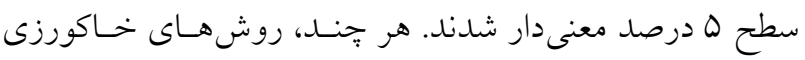
ديخر، تفاوت آمارى معنى دارى با هم در سطح ه درصـد نشـان ندادند (جدول V). بيشترين ميزان كربن آلى و ترسيب كربن در

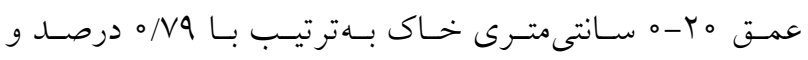
l o/OVD

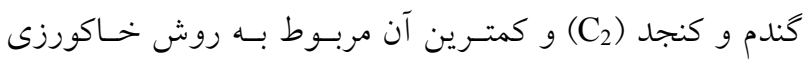

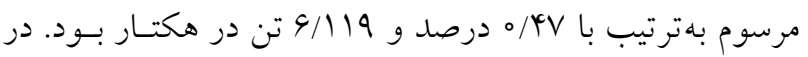
اين عمق، روش كشت مستقيم گندم و كنجل، ميزان كربن آلى و ترسيب كربن در خـاى را نسـبت بـه روش خـاكورزى مرسـوم بهترتيب به ميزان ه 9N/I و VY/AY درصــ افـزايش داد كـه ايسن افزايش در مقايسه با افزايش در لايه ه ا-ه سـانتى متـرى خـاك كمتر است. از آنجا كه روشهاى مختلف خـاكورزى حفـاظتى، بيشتر باعث تغيير در لايسه سـطحى خـاك مسىشـوند و بقايـاى كياهى نيز در سطح خاى قرار مى گيرد، طبيعى اسـت كـه ايسن روشها بيشترين تأثير را بر ميزان مواد آلى لايسه سـطحى خـاك داشته باشند. درصورتى كه روش خاكورزى مرسوم با بههم زدن كامل خاك باعث تسريع اكسايش مواد آلى خاك و درنتيجه آزاد شدن سريعتر عناصر غذايى مىشود و امكان هـدرروى كـربن و
كشت مستقيم كندم و كنجد (C2) باعث شــ درصـد كـربن آلى لايه ه ا-ه سانتى مترى خـاك نسـبت بـه روش خـاكورزى

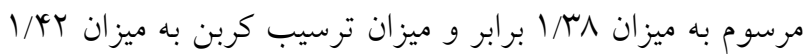

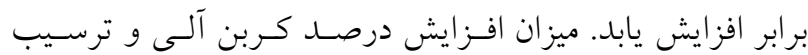

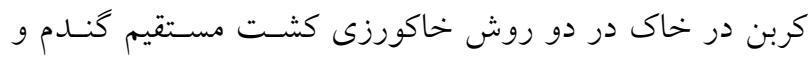
كشت مرسوم كنجد در سال سوم (C) و كشت مستقيم كنجد و كشت مرسوم كُندم در سال سوم (C44)، كمتـــ از ميـزان افـزايش ناشى از كاربرد روش خاكورزى كشت مسـتقيم گنــدم و كنجـــ بود كه نشاندهنده تأثير منفى عدم استمرار كشت مستـقيم $\left(C_{2}\right)$

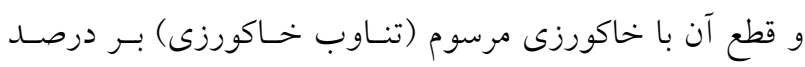
كربن آلى و ترسيب كربن در خـاك اسـت. همجنــين، در عمـق •ا-ه سانتىمترى خاك، درصد كربن آلى و ميزان ترسيب كربن در خاك ناشى از كاربرد روش كم خاكورزى (C) نيز بيشـتر از درصد كربن آلى و ميزان ترسيب كربن در خاى ناشى از كاربرد

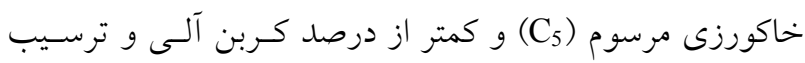
كربن در خاك در روش كشت مستقيم (C22) بود. كاهش درصـا كربن آلى و ميزان ترسيب كـربن در خـاك در روش خـاكورزى مرسوم بهدليل زيرورو شدن كامل خاك در اثر شخم با خـاوآهن بركرداندار است. زيرا بههم خوردن خاك باعـث تهويسه بيشـتر شده و تجزيه ميكروبى مواد آلى خاى را تسريع كرده و تلفـات آن را افزايش مىدهد. مقايسه ميانكين درصد كربن آلى و مقدار ترسيب كربن در خـاك در عمـق ه广-ه سـانتى متـرى خـاك در 


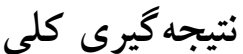

با توجه به اينكه مساحت زيادى از زمينهاى كشاورزى در دنيـا و از جمله ايران (حسدود •ها ميليـون هكتـار) در اثـر عمليـات

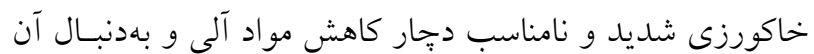

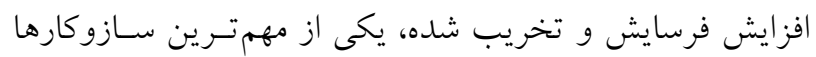

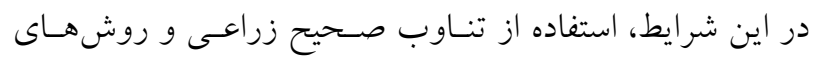

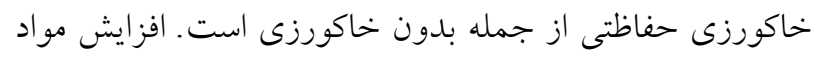

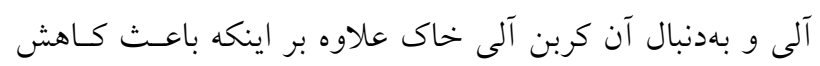

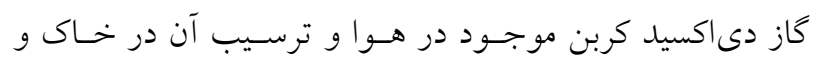

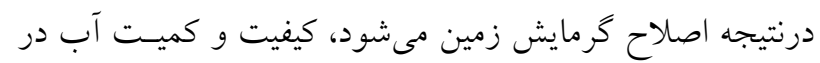
عرصه، كيفيت هوا، كميت و كيفيت محصول و امنيت غـذايى را

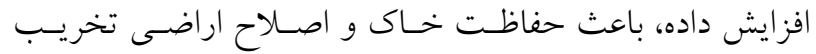

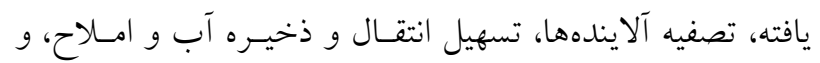
بهبود زيست بومها مىشود. كـاربرد روش بـــون خـاكورزى در تناوبهاى گندم- ينبه و گندم - كنجد در طى جهار سال باعـث شد ميزان كل ترسيب كربن در عمق هب- هـ سـانتىمترى خـاك نسبت به روش خاكورزى مرسوم بـهـترتيـب بـهميـزان

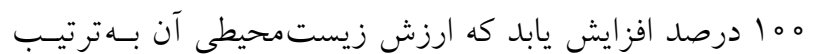

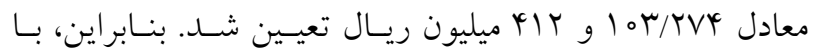
توجه به مزاياى ديخر روشهاى خـاكورزى حفـاظتى از جملـه كاهش مصرف سوخت و افزايش ظرفيت مزرعهاى مـؤثر انجـام

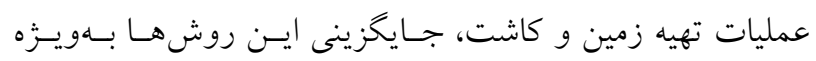

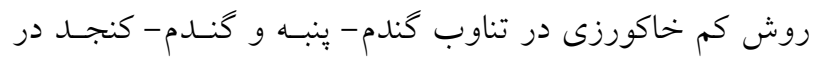

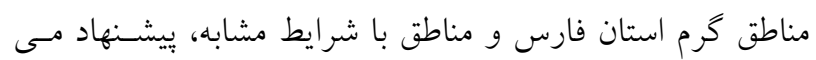

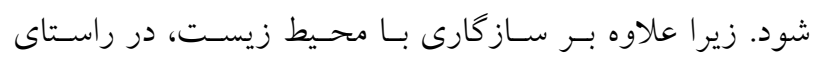
پايدارى توليد بوده و از نظر اقتصادى نيز مقرون بهصرفه هستند.
ساير عناصر غذايى را افزايش مىدهد. در مقايسه بـا خـاكورزى

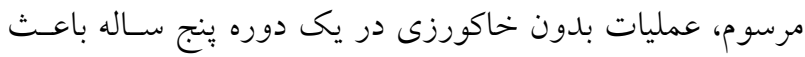

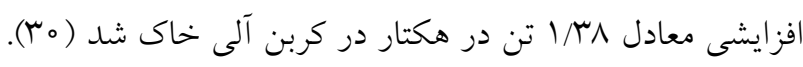

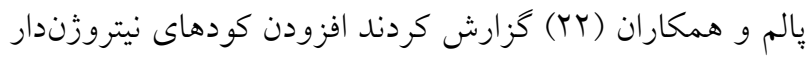

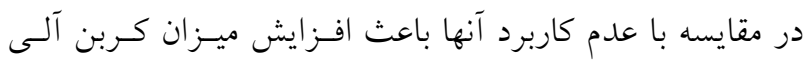

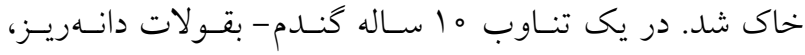

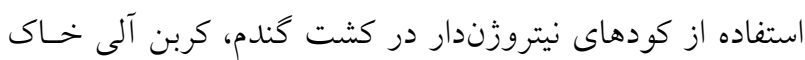

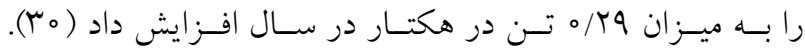
درويش و همكاران (V) كزارش كردند كشـت بـاقلا و خلـر در ميان نوارهاى كشت جو باعث افزايش معنىدار ميزان كربن آلى

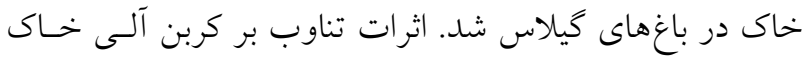
به مقدار زيست توده هوايى و زيرزمينسى توليسـ شــهـ بـهوسـيله كَاهان كاشته شده و بخشى از اين زيست توده كه در خاك باقى مى ماند بستخى دارد (1). ماسرى و ريان (19) خزارش كردند كه

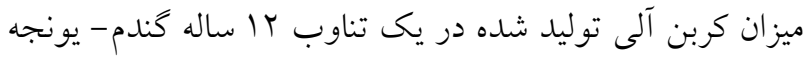

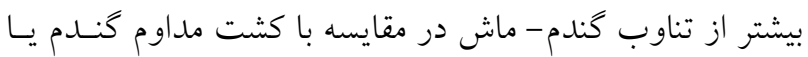

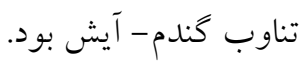

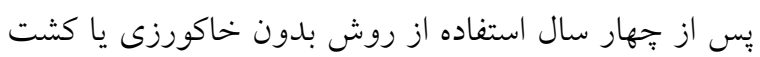

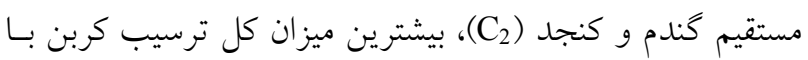

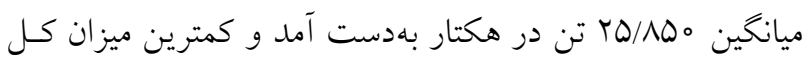

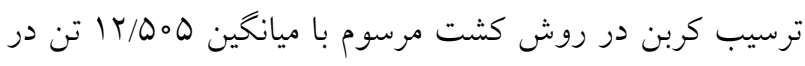

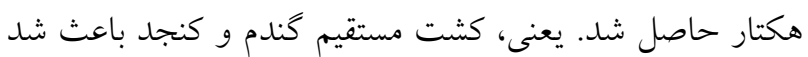

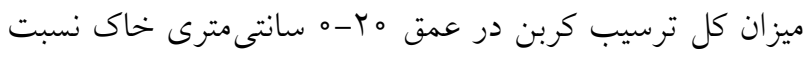

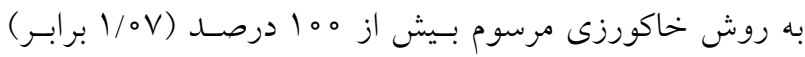
افزايش يابد كه ارزش زيستمحيطى ميزان كل ترسيب كربن در اين عمق نسبت به روش كشت مرسوم معادل rأب ميليون ريـال

\section{منابع مورد استفاده}

1. Alijani, Kh., M. J. Bahrani and S. A. Kazemeini. 2012. Short-term responses of soil and wheat yield to tillage, corn residue management and nitrogen fertilization. Soil and Tillage Research 124: 78-82.

2. Atallah, T., C. Jamous, P. Debs and T. Darwish. 2012. Biosolid recycling to enhance carbon sequestration in mountainous Lebanese conditions. Lebanese Science Journal 13: 69-79. 
3. Batjes, N. H. and W. G. Sombroek. 1997. Possibilities for carbon sequestration in tropical and subtropical soils Global Change Biology 3: 161-173.

4. Bisheng, W., G. Lili, W. Yu, X. Wei, J. Li, Sh. Li, X. Song, G. Liang, D. Cai and X. Wu. 2019. Distribution of soil aggregates and organic carbon in deep soil under long-term conservation tillage with residual retention in dryland. Journal of Arid Land: 11(2): 241-254. https://doi.org/10.1007/s40333-019-0094-6.

5. Boukhoudoud, N., R. Gros, T. Darwish and A. M. Farnet Da Silva. 2016. Agriculture practice and coastal constraint effects on microbial functional properties of soil in Mediterranean olive orchards. European Journal of Soil Science 67: 470-477. https://doi.org/10.1111/ejss.1234.

6. Cerdà, A., F. Gonzalez Penaloza, C. Santin and S. H. Doerr. 2012. Land abandonment, fire recurrence and soil carbon content in the Macizo del Caroig, Eastern Spain. Geophysics Research Abstracts 14: EGU2012-14331.

7. Darwish, T. M., I. Jomaa, T. Atallah, S. Hajj, A. Shaban, R. Zougheib and F. Sibai Ouayda. 2012. An agropastoral system as a practice to enhance organic matter in Lebanese inland mountainous soils. Lebanese Science Journal 13: $1-14$.

8. Darwish, T., T. Atallah and A. Fadel1. 2017. Challenges of soil carbon sequestration in the NENA region. Soil 4: 225-235.

9. Falloon, P. D., P. Smith, J. U. Smith, J. Szabó, K. Coleman and S. Marshall. 1998. Regional estimates of carbon sequestration potential: linking the Rothamsted Carbon Model to GIS databases. Biology and Fertility of Soil 27(3): 236-241.

10. Follett, R. F., J. Z. Castellanos and E. D. Buenger. 2005. Carbon dynamics and sequestration in an irrigated Vertisol in Central Mexico. Soil and Tillage Research 83: 148-158.

11. Hu, S., D. C. Coleman, M. H. Beare and P. F. Hendrix. 1995. Soil carbohydrates in aggrading and degrading agroecosystems, influences of fungi and aggregates. Agricultural Ecosystems and Environment 54: 77-88.

12. Johnson, M. G. and J. S. Kern. 1991. Sequestering carbon in soils: A workshop to explore the potential for mitigating global climate change. USEPA Rep. 600/3- 91-031. USEPA Environ. Res. Lab, Corvallis, OR.

13. Ghaesminejad Raeini, M. and H. Sadeghi. 2017. The evaluation of carbon sequestration at plant's organs and soil characteristics in understory of Zygophyllum atriplicoides and Gymnocarpus decander (Case study: Saleh-Abad, Hormozgan). Iranian Journal of Range and Desert Research 24(4): 699-707. (In Farsi).

14. Guo, L. J., S. Lin, T. Q. Liu, C. G. Cao and C. F. Li. 2016. Effects of conservation tillage on topsoil microbial metabolic characteristics and organic carbon within aggregates under a rice (Oryza sativa L.)-wheat (Triticum aestivum L.) cropping system in Central China. PLoS One 5: e0146145, https://doi.org/10.1371/journal.pone.0146145.

15. Khorramdel, S., P. Rezvanimoghaddam and L. Jafari. 2016. Evaluating the potential of carbon sequestration for canola fields under Khorasan Razavi Province. Journal of Crop Production 9(3): 22-43. (In Farsi).

16. Kooch, Y., S. M. Hosseini, C. Zaccone, H. Jalilvand and S. M. Hojjati. 2012. Soil organic carbon sequestration as affected by afforestation: the Darab Kola forest (north of Iran) Case study. Journal of Environmental Monitoring 14: 2438-2446.

17. Lal, R. and J. M. Kimble. 1997. Conservation tillage for carbon sequestration. Nutritional Cycling Agroecosystems 49(1-3): 243-253.

18. Mc Conkey, B. G., B. C. Liang, C. A. Campbell, D. Curtin, A. Moulin, S. A. Brandt and G. P. Lafond. 2003. Crop rotation and tillage impact on carbon sequestration in Canadian prairie soils. Plant and Soil 74(1): 81-90.

19. Masri, Z. and J. Ryan. 2006. Soil organic matter and related physical properties in a Mediterranean wheat-based rotation trial. Soil and Tillage Research 87: 146-154.

20. Moradi, R., A. Koocheki, M. Nassiri Mahallati and H. Mansoori. 2015. Effect of tillage, residue management and nitrogen fertilizer on carbon balance and global warming potential in maize cultivation. Journal of Agricultural Science and Sustainable Production 25(1): 29-44. (In Farsi).

21. Moreno, G., J. J. Obrador and A. Garcia. 2007. Impact of evergreen oaks on soil fertility and crop production in intercropped dehesas. Agriculture, Ecosystems and Environment 119: 270-280.

22. Palm, Ch., H. Blanco-Canqui, F. DeClerck, L. Gatere and P. Grace. 2014. Conservation agriculture and ecosystem services: An overview. Agriculture, Ecosystems and Environment 187: 87-105. https://doi.org/10.1016/j.agee.2013.10.010.

23. Plaza-Bonilla, D., J. L. Arrúe, C. Cantero-Martínez, R. Fanlo, A. Iglesias and J. Álvaro-Fuentes. 2015. Carbon management in dryland agricultural systems, A review. Agronomy Sustainable Development 35: 1319-1334.

24. Pato, M., A. Salehi, Gh. Zahedi Amiri and A. Banej shafiei. 2017. Soil carbon stock and its relationship with physical and chemical characteristics in soil of different land-uses in Zagros region. Journal of Forest and Wood Products (JFWP) (Iranian Journal of Natural Resources) 69(4): 747-756. (In Farsi).

25. Safari Sanjaby, A. A. 2003. Soil biology and biochemistry. Bu-Ali Sina University Press, Hamedan. (In Farsi).

26. Post, W. M., T. H. Peng, W. R. Emmanuel, A. W. King, V. H. Dale and D. L. De Angelis. 1990. The global carbon cycle. American Science 78: 310-326. 
27. Rivers, N. 2014. The Case for a carbon tax in Canada, Canada 2020. Article available at http://canada2020.ca/canadacarbon-tax/.

28. Schuman, G. E., H. Janzen and J. E. Herrick. 2002. Soil carbon information and potential carbon sequestration by rangelands. Environmental Pollution 116: 391-396.

29. Sharma, P., V. Abrol, S. Abrol and R. Kumar. 2012. Climate change and carbon sequestration in dryland soils, In: Tech open access book, chap. 6, https://doi.org/10.5772/52103 (last access: 31 July 2018).

30. Sommer, R., C. Piggin, D. Feindel, M. Ansar, L. van Delden, K. Shimonaka, J. Abdalla, O. Douba, G. Estefan, A. Haddad, R. Haj-Abdo, A. Hajdibo, P. Hayek, Y. Khalil, A. Khoder and J. Ryan. 2014. Effects of zero tillage and residue retention on soil quality in the Mediterranean region of northern Syria. Open Journal of Soil Science 4: 109125. https://doi.org/10.4236/ojss.2014.43015. 


\title{
The Effect of Tillage Methods in Wheat-Cotton and Wheat-Sesame Rotations on the Soil Carbon Sequestration
}

\author{
M. J. Rousta ${ }^{*}$, S. Afzalinia ${ }^{2}$ and A. Karami ${ }^{3}$
}

(Received: May 20-2019; Accepted: July 31-2019)

\begin{abstract}
Given the various advantages of applying conservation tillage methods in the agriculture, including reducing the effects of climate change by decreasing the carbon dioxide emissions to the atmosphere caused by carbon sequestration in soil, this study was conducted with two wheat-cotton and wheat-sesame rotations at Agricultural Research Station Bakhtajerd, in Darab, the southeast of Fars Province, which had a warm and dry climate; this work was carried out in a loam soil during four years. The aim of this investigation was to compare the carbon sequestration (CS) in the soil after application of different conservation tillage methods with the conventional method. The results showed that in wheatcotton rotation, the maximum and minimum amount of CS in the $0-20 \mathrm{~cm}$ depth of soil with the average 17.160 and 13.810 t/ha could be obtained by using no-till and conventional tillage, respectively. Therefore, no-till increased CS by $24.26 \%$ in wheat and cotton cultivation, as compared to the conventional tillage. The economic value of this CS increment for the environment was $\$ 2459$ per hectare. In the wheat-sesame rotation, the highest and lowest CS was obtained with an average of 25.850 and $12.505 \mathrm{t} / \mathrm{ha}$ in no-till and conventional tillage, respectively. Namely, direct seeding of wheat and sesame increased the CS at the $0-20 \mathrm{~cm}$ depth of soil by $107 \%$, as compared to the conventional tillage with the economic value of $\$ 9809.5$ per hectare. Under similar conditions, in wheat-cotton and wheat-sesame rotations, the conventional methods could be replaced by no tillage.
\end{abstract}

Keywords: Carbon sequestration, Conservation tillage, Fars province, Rotation

1. Agricultural Research, Education and Extension Organization (AREEO), Soil Conservation and Watershed Management Research Department, Fars Agricultural and Natural Resources Research and Education Center, Shiraz, Iran.

2. Agricultural Research, Education and Extension Organization (AREEO), Agricultural Engineering Research Department, Fars Agricultural and Natural Resources Research and Education Center, Shiraz, Iran.

3. Agricultural Research, Education and Extension Organization (AREEO), Soil and Water Research Department, Fars Agricultural and Natural Resources Research and Education Center, Shiraz, Iran.

*: Corresponding author, Email: mjrousta@yahoo.com 